\title{
Drones in Carbonate Geology: Opportunities and Challenges, and Application in Diagenetic Dolomite Geobody Mapping
}

\author{
M. Y. A. Madjid ${ }^{1}$, V. Vandeginste ${ }^{1,2, *}$, G. Hampson ${ }^{1}$, C.J. Jordan ${ }^{3}$, A.D. Booth ${ }^{4}$, \\ ${ }^{1}$ Qatar Carbonates and Carbon Storage Research Centre and Department of Earth Science and Engineering, \\ Imperial College London, UK \\ ${ }^{2}$ GeoEnergy Research Centre and School of Chemistry, University of Nottingham, University Park, NG7 2RD, \\ Nottingham, UK \\ ${ }^{3}$ British Geological Survey, Environment Science Centre, Keyworth, NG12 5GG, Nottingham, UK \\ ${ }^{4}$ School of Earth and Environment, University of Leeds, Woodhouse Lane, Leeds LS2 9JT, UK
}

* Corresponding author. School of Chemistry, University of Nottingham, University Park, NG7 2RD, Nottingham, UK. Email: veerle.vandeginste@nottingham.ac.uk

\section{ABSTRACT}

Unmanned aerial vehicles (UAVs) or drones have become widely available for use in a broad range of disciplines. Despite the decreased cost and technological developments of platforms, sensors and software, the use of drones in carbonate geology has yet to be exploited. Nevertheless, drones offer multiple advantages over traditional field work or high-altitude remote sensing techniques, in that they enable the reconstruction of three dimensional models of inaccessible or unsafe outcrops, and can bridge the spatial scale gap in mapping between manual field techniques and airborne, high-altitude remote sensing methods. In this contribution, we present our methodology of structure from motion photogrammetry on dronecaptured images and highlight opportunities and challenges of using drones in carbonate geological studies. Moreover, we apply this method to document the spatial distribution and dimensions of diagenetic dolomite geobodies in Carboniferous limestone host rock of the Picos de Europa, northern Spain. The results of our study indicate that dolomite geobodies occur preferentially near to strike-slip faults, rather than thrust faults or specific types of limestone host rock lithology, in the study area. The geobody dimensions appear to be related to the strain magnitude of the strike-slip faults. We propose that these identified links and controls are applicable to structurally-controlled dolomitization on a more general basis. Our study has demonstrated the potential for using drones in carbonate geological studies. 


\section{Introduction}

In the last decade, unmanned aerial vehicles (UAVs) or drones have become widely available for use in a broad range of disciplines (Watts et al., 2012). The success and popularity of these platforms have significantly decreased their market cost, and have driven technological developments of the platforms themselves, their sensors and software systems. The widespread presence of tried-and-tested rotary and fixed-wing platforms in the market place, allied to the speed of miniaturisation and development of novel sensors, enable innovative applications. Important advantages over traditional remote sensing systems include greater cost effectiveness, higher resolution small budget platforms, and the flexibility to acquire data while in the field when conditions are appropriate. There are various forms of commerciallyavailable drones encompassing rotary and fixed-wing, each with associated flight characteristics and limitations such as the ability for vertical take-off and landing (VTOL) and the requirement for various sizes of landing zones. Drones are revolutionizing scientific research in multiple fields including archaeology (De Reu et al., 2016), natural hazards (Jordan and Napier, 2016; Mateos et al., 2017; Serban et al., 2016; Tamminga et al., 2015), ecology (Anderson and Gaston, 2013; Faye et al., 2016; Flynn and Chapra, 2014; Ouedraogo et al., 2014; Ventura et al., 2016; Yang et al., 2014), forestry (Masek et al., 2015; Padua et al., 2017; Paneque-Galvez et al., 2014; Puliti et al., 2015; Sankey et al., 2017; Tang and Shao, 2015), sedimentary geology (Chesley et al., 2017; Nieminski and Graham, 2017), glaciology (Bhardwaj et al., 2016; De Michele et al., 2016; Westoby et al., 2015), geothermal research (Nishar et al., 2016), atmospheric chemistry (Caturegli et al., 2016; Schrod et al., 2017), hydrology (Bandini et al., 2017; Spence and Mengistu, 2016), mining (Jakob et al., 2017; Tong et al., 2015), environmental science (Hird et al., 2017; Mlambo et al., 2017; Sanders and Masri, 2016), and structural geology (Bemis et al., 2014).

Although drones can play an important and innovative role in numerous applications, the use of drones in carbonate geology has not yet been exploited much. As far as the authors are aware of, there are at the time of writing this contribution, only two publications that focus on the application of drones in sedimentological studies, both documenting siliciclastic systems (Chesley et al., 2017; Nieminski and Graham, 2017). Most carbonate geological studies rely on detailed description of sedimentological strata and characteristics, diagenetic features and/or structural phenomena. Essential in these studies is mapping and documenting continuous sections, or correlating (with a high degree of confidence) strata in different outcrops. Accessibility to outcrops is thus critical. However, ancient carbonate platforms are often exposed in the field in very steep cliff faces, such as the Natih Formation at Jebel Shams in Oman (Arndt et al., 2014; Homewood et al., 2008), the Guadalupe Mountains in West Texas and New Mexico (Budd et al., 2013; Kerans et al., 2017), the Jurassic Amellago cliffs in Morocco (Bodin et al., 2010; Merino-Tome et al., 2017). The use of drones can overcome much of this challenge of accessibility to outcrops (Nieminski and Graham, 2017). Although sampling rock material from cliff faces is not feasible yet with the use of drones, important sedimentological, diagenetic and structural information can be collected through close-range aerial photography or more advanced imaging techniques. Importantly, this detailed data collection from inaccessible outcrops enables the possibility of more quantitative geoscientific studies, as illustrated in this paper. Applying drones in sedimentary geological studies provides a low-cost, easy method that helps in the documentation and interpretation of small to intermediate scale features in sedimentary rocks (Chesley et al., 2017). Compared to traditional remote sensing systems based on satellite and aerial photography, photogrammetry and ground based laser scanning systems, drones offer the opportunity to fill the gap in effective spatial range and resolution of low-altitude flights with the flexibility of documenting horizontal, inclined and vertical surfaces.

Here, we have applied drone remote sensing to document the spatial distribution of diagenetic dolomite geobodies. The particular importance of mapping diagenetic geobodies in carbonate rocks lies in the critical aspect of characterising heterogeneity, which can be sedimentological, structural and diagenetic in origin, and is key to understand and predict reservoir quality and 
performance in subsurface reservoirs. Diagenetic alteration in carbonate reservoirs is generally more extensive than in siliciclastic reservoirs, since carbonate minerals are more reactive than quartz (Ehrenberg and Nadeau, 2005). Since diagenetic heterogeneities are often subseismic in scale, gathering information from outcrop analogues provides important information at a critical spatial scale (Vandeginste et al., 2015b). The use of drones in addition to manual sampling fills crucial gaps in continuity of documenting exposed sections by covering inaccessible parts and in high-resolution mapping of subseismic-scale heterogeneities by comparatively brief field surveys. The Carboniferous carbonate outcrops of the Picos de Europa National Park in northern Spain (Figure 1) are well studied and are considered reference outcrops for the Carboniferous (Bahamonde et al., 2000; GomezFernandez et al., 2000; Merino-Tome et al., 2009). The outcrop conditions of the carbonates in the Picos de Europa make them an ideal candidate to evaluate the use of drone technology. We captured photographic images using a small drone to create a high resolution threedimensional (3D) digital outcrop model by integrating the digital surface model (DSM) with an assemblage of rectified aerial photographs (orthomosaic, which is a two-dimensional planar image containing coordinate position and colour information at each pixel, that has been corrected in terms of different camera perspectives). We explain this methodology for field mapping, discuss the opportunities and challenges of using drones in carbonate geological applications and interpret the results of our study in the framework of carbonate diagenesis and its implications for hydrocarbon reservoirs. This study illustrates the quantitative approach that can be achieved in geosciences using an inexpensive method.

\section{Geological setting}

The Picos de Europa tectonic unit is situated in the Cantabrian Zone (Figure 2) which is part of the Iberian Massif. This Massif is the Western European part of the Variscan orogenic belt, which was generated due to the continental collision of Gondwana, Laurentia, and periGondwana microplates during the late Paleozoic. The shape of the Cantabrian zone depicts typical features of a foreland basin developed via a thin-skinned deformation mechanism and fold-and-thrust imbrication of a thick sequence of Paleozoic strata (Merino-Tome et al., 2009). The Cantabrian zone is divided into ten tectonic units based on the integration of stratigraphic and structural characteristics (Weil et al., 2013).

From Late Paleozoic to present day, the Cantabrian zone has undergone several tectonic episodes. The main tectonic events include: 1) Compression in the Late Carboniferous with the emplacement of east-west thrusts of the Picos de Europa Province over the Palentine Zone or Pisuerga-Carrión province (Gomez-Fernandez et al., 2000); 2) Extension in the late Carboniferous-Permian along sub-vertical faults that are oriented $\mathrm{N} 105^{\circ}$ to $120^{\circ} \mathrm{E}$, and in the north of the Picos de Europa province, along some of the east-west sub-vertical thrusts (Gomez-Fernandez et al., 2000), Merino-Tome et al. (2009) attributed this extensional episode to the formation of wrench and normal faults that cut previous structures due to North Atlantic rifting; 3) The Late Eocene Alpine Orogeny with uplift and emergence of the Paleozoic Asturian Massif and overlying Mesozoic sediments (Gomez-Fernandez et al., 2000).

The Carboniferous stratigraphy in the Picos de Europa unit is characterized by pre-orogenic stratigraphic sequences that consist of dolomitized limestone overlain by syn-orogenic stratigraphic sequences that consist of predominantly shale (Gomez-Fernandez et al., 2000) (Figure 3). This study focuses on the upper part of pre-orogenic sequences which are known as the Caliza de Montaña Group (Montaña Beds) and Picos de Europa Formation. The Montaña Beds consist of two formations, namely the Barcaliente Formation and the Valdeteja Formation. The Barcaliente Formation is characterized by basinal sequences of well-bedded, dark, microlaminated and non-fossiliferous lime mudstones, whereas the Valdeteja Formation consists of $300 \mathrm{~m}$ of thick-bedded carbonate breccias of micritic lithoclasts and microlaminated mudstones separated by thin, well-bedded graded grainstones with spiculitic alternations (Bahamonde et al., 2000). The Picos de Europa Formation is characterized by interbedded 
limestones and shales in the lower part and massive bioclastic limestone in the upper part (Gomez-Fernandez et al., 2000).

\section{Methodology}

Fieldwork was conducted in the Picos de Europa national park, Northern Spain, where we deployed a drone to capture overlapping aerial photographs in order to document the spatial distribution of dolomite geobodies. Detailed outcrop observation of selected geobodies was also carried out on the ground, to collect additional information on dolomite geobody texture, colour, and dolomite-limestone contacts which served as validation for the drone mapping of spatial dolomite distribution.

In this study, we used a DJI Phantom III Professional drone (quadcopter) with a mounted 12 Mega Pixel digital camera that can tilt 0 to $90^{\circ}$. Before conducting drone mapping, we selected flight paths and areas for each flight mission. Before take off, calibrations were made to ensure the platform was orientated prior to take-off. For each flight mission, we selected the drone take-off area generally at the top of a hill and in the centre of the survey area in order to cover the area effectively. For most missions, the drone was set to take aerial photographs using "autopilot mode" with a camera facing directly downwards for a hilly terrain. A few surveys were conducted with the camera mounted $45^{\circ}$ sideways to enable high-quality capture of data from steep cliff faces. We selected 70 to $90 \%$ forward and sideways overlap of images. We carried out more than 80 flight missions, capturing a total of 4,606 pictures, and mapped in total an area of about $3.7 \mathrm{~km}^{2}$ in seven and a half days of drone field work with a capacity of six drone batteries.

There are several software packages available, both free and paid versions, that can be used to create digital surface models and orthomosaic from the drone captured photographs. In this study, we used Pix4DMapper Pro software which applies Structure from Motion (SfM) photogrammetry to process raw images from the drone.

SfM photogrammetry identifies a key feature (key-point) from overlapping images automatically and reconstructs it within 3D space as a single point without knowing the camera position and scene geometry (Westoby et al., 2012). The camera position and scene geometry are reconstructed by the automatic identification of the identical key-points in multiple images (Westoby et al., 2012). These key-points are traced in every individual image which are then processed iteratively using non-linear least squares minimisation (Snavely et al., 2008) so that the original camera positions and object coordinates (tie-point) can be estimated (Westoby et al., 2012) (Figure 4). In addition, we selected a few ground control points for each flight mission. Subsequently, 3D models (e.g. point clouds) are created from the images by using multi-view-stereo algorithms (Chesley et al., 2017; Seitz et al., 2006; Westoby et al., 2012).

A standard SfM workflow (Chesley et al., 2017; Westoby et al., 2012) has typically five steps: 1) Identification of key-points and creating feature descriptors using Scale Invariant Feature Transform (SFIT) object recognition system (Snavely et al., 2008); 2) Matching of all identical key-points between images; 3) Estimating camera position, reconstruction of scene geometry and 3D position using triangulation methods to create 3D low-density (sparse) point clouds; 4) Point cloud densification; 5) DSM and orthomosaic generation. In our study, due to a huge number of raw images, processing was divided into two levels based on coverage area, such as a full study area and seven smaller areas with higher resolution. The processing quality of each model is documented in Table 1.

The distinction of dolomite bodies was made primarily based on colour difference, as discussed in the results section below. The bodies were then mapped manually on the orthomosaic using ArcGIS software. Dolomite mapping was carefully conducted particularly close to areas that were extensively covered by vegetation, snow patches, and abandoned mine pits. Subsequently, three-dimensional geometrical characteristics of dolomite bodies 
such as length, width and height were calculated from mapped dolomite polygons in ArcGIS software. The texture and 3D characteristics of the DSM were mainly of importance in the calculation of the dimensions of the bodies, whereas the distinction between dolomite and limestone was made from the orthomosaic, primarily based on colour. Length and width estimates of dolomite bodies were generated using the "minimum bounding geometry" toolbox, with the smallest box width as the boundary. This method creates a rectangular geometry covering the true irregular dolomite shape and generates length and width values automatically, as well as the orientation of the long axis of the rectangle. The height of dolomite bodies was derived from the integration of mapped dolomite polygons with the DSM. All dolomite polygons were assigned to the DSM using the "interpolate shape" toolbox, and a height value was created by subtracting the difference between minimum and maximum elevations ( $Z$ value) of the bodies.

\section{Results}

\subsection{Models}

Two levels of models were generated with different resolutions, to enable smooth handling with consumer-grade computers. A DSM and orthomosaic of the full study area was created at a resolution of $25 \mathrm{~cm}$ (Figure 5), whereas seven smaller DSMs and orthomosaic models were created for parts of the study area at a higher resolution of approximately $10 \mathrm{~cm}$. The high-resolution models were used to identify small-scale dolomite bodies that are challenging to distinguish in the lower resolution model, and this information was then transferred to the model of the full study area. The geological map of the Careña-Cabrales area (Garcia et al., 1977) and the DSM were used as a base for identification and interpretation of stratigraphic and structural features in our model. Two stratigraphic units, three strike-slip faults, and two thrust faults are identified in the study area. Furthermore, we created a fault proximity map in the ArcGIS software to assess abundance and size of dolomite bodies in the proximity of faults in the study area, in the context of our investigation of the potential structural control on dolomitization (Figure 6).

\subsection{Mapping of Dolomite Bodies}

Dolomite geobodies can be distinguished from the limestone host rock by their texture and colour contrast. Dolomite appears more brownish and blackish in colour, is highly fractured, and has an irregular shape with sharp and discordant contacts with limestone host rock. In contrast, limestone is commonly characterized by light grey colour, less fractured appearance and more massive texture (Figure 7). The dolomite cuts through limestone beds, and there are a few remnants of pre-existing limestone host rocks enclosed by dolomite bodies. The dolomite - limestone contacts are sharp and irregular (Figure 7). The brown dolomite colour versus grey limestone colour (on the pictures taken by drone) is the surface or weathering colour in the outcrop, which can be slightly different than fresh rock surfaces. A colour contrast between limestone and dolomite has been described also in study areas in Iran (Lapponi et al., 2011; Sharp et al., 2010), Italy (Bistacchi et al., 2015; Jacquemyn et al., 2015), Oman (Beckert et al., 2015; Vandeginste et al., 2015a), Spain (Dewit et al., 2012; Vandeginste et al., 2015b), United Arab Emirates (Fontana et al., 2010), and elsewhere. The weathering colour is linked to: 1) the chemistry of the rocks, for example, iron-rich rocks show a rusty brown weathering colour (Beckert et al., 2018; Vandeginste and John, 2012; Vandeginste et al., 2015a), and 2) the rock texture and mineralogy, fine grained limestone with some clay impurities or organic material is generally grey, whereas coarse crystalline dolomite has a light or brownish colour (Vandeginste et al., 2005). The limestone host rock in the Picos de Europa Formation consists of bioclastic packstones and grainstones with a fine grained muddy matrix and fragments of sponges, ooids, foraminifera, coralline algae, microbial mats, crinoids and gastropods, whereas the dolomite bodies have a fabric-destructive coarse-crystalline texture with dolomite crystals from 0.4 to $3 \mathrm{~mm}$ that have growth zones identified using cathodoluminescence microscopy (Racine, 2017). The dolomite has higher concentrations of iron, manganese and barium compared to the limestone (Racine, 2017), which influences the weathering colour. The microscopic features of the host limestone and dolomite in the studied 
formations have also been described and illustrated by Bahamonde et al. (2000) and GomezFernandez et al. (2000). Fluid inclusion data demonstrate that the dolomitizing fluids were highly saline, $20-23 \mathrm{wt} \% \mathrm{NaCl}$ eq., and relatively warm, $100-170^{\circ} \mathrm{C}$ (Racine, 2017). Similarly, Gomez-Fernandez et al. (2000) reports temperatures of $170-200^{\circ} \mathrm{C}$ and salinities of around $15 \mathrm{wt} \% \mathrm{NaCl}$ eq. for dolomite in the Picos de Europa area.

In addition to mapping on the 3D models, we conducted checks in the field by direct observation of dolomite bodies in the outcrops matched to the locations in the models. In our analysis, we grouped the dolomite bodies based on the stratigraphic unit they are hosted in. In total, more than 400 dolomite bodies were mapped in the study area, with a predominant occurrence of the bodies in the Montaña Beds. The percentage surface area of dolomite bodies within the Montaña Beds is around 3\%, whereas in the Picos de Europa Formation it is around $1 \%$, with the total surface area of the bodies being around $0.07 \mathrm{~km}^{2}$ (Figure 8). Dolomite bodies cannot be determined in some areas that are extensively covered by vegetation, scree, and abandoned mine pits. The total surface area of the undetermined zone is around $0.40 \mathrm{~km}^{2}$.

\subsection{Spatial Distribution of Dolomite Geobodies}

The two lithostratigraphic units in the study area contain several limestone host rock lithologies, including microlaminated lime mudstones and inter-bedded carbonate breccias and grainstones in the Montaña Beds (Bahamonde et al., 2000), and massive limestones and interbedded limestones and shales in the Picos de Europa Formation (Gomez-Fernandez et al., 2000). There is little apparent difference in the distribution of dolomite bodies between the Montaña Beds and the Picos de Europa Formation (Figure 8), although dolomite bodies form a greater proportion of the surface area of the Montaña Beds (3\%) than of the Picos de Europa Formation (1\%). Although the primary fabrics of the limestone host rock lithologies have been extensively modified locally by dolomitization, the distribution of dolomite bodies does not pick out stratigraphic units or conform to stratigraphic contacts (e.g. the boundary between the Montaña Beds and the Picos de Europa Formation in Figure 8, as mapped by Garcia et al., 1977). Instead, dolomite bodies appear to occur in clusters that tend to be aligned along and lie in close proximity to the surface traces of strike-slip faults, as described below. This dominant link of dolomite bodies with strike-slip faults is clear on the larger (> meter) scale. At the smaller (decimeter) scale, the discordant dolomite-limestone contact is to some extent affected by bed-scale lithological difference, as the irregular contact line may show small extensions in certain beds, similar to structures discussed in Vandeginste et al. (2013).

The distribution of the dolomite bodies is slightly more concentrated close to strike-slip faults in the study area (Figure 9). Most of the Montaña Beds hosted dolomites are located near the San Carlos Fault, whereas almost all Picos de Europa hosted dolomites are located near either the Middle Fault or the Northern Fault. The number and the total surface area of dolomite bodies both exhibit an overall decrease away from the San Carlos Fault in a $600 \mathrm{~m}$ wide zone. A total of 185 bodies are concentrated within $100 \mathrm{~m}$ of the fault. The total surface area of the dolomite is more than $31,000 \mathrm{~m}^{2}$.

For the dolomite bodies that are located near the Middle Fault, the number and the total surface area of dolomite bodies also generally decrease away from the fault. Within a distance of $100 \mathrm{~m}$ from the fault, there are 54 dolomite bodies with a total surface area of more than $3,700 \mathrm{~m}^{2}$. It is interesting to note that there is a large dolomite body located about $270 \mathrm{~m}$ away from the fault with a surface area of more than $800 \mathrm{~m}^{2}$, whereas the total surface area of surrounding bodies does not exceed $300 \mathrm{~m}^{2}$.

In the area of the Northern Fault, the number of dolomite bodies also generally decreases with distance from the fault. Although a similar trend of decreasing dolomite total surface area with distance from the fault is observed, the trend is different within a $30 \mathrm{~m}$ range of the fault. A total of 45 dolomite bodies with a total surface area of more than $4,700 \mathrm{~m}^{2}$ occur within $50 \mathrm{~m}$ distance of the fault. 
Compared to the presence of dolomite bodies close to strike-slip faults, there seems to be a much smaller number of bodies located close to thrust faults. The distribution of the number of dolomite bodies in the area around the Northern Thrust is quite irregular, whereas the total surface area of the geobodies generally increases away from the thrust fault. There are only two dolomite geobodies of area $162 \mathrm{~m}^{2}$ within $150 \mathrm{~m}$ of the Southern Thrust, which represents a population that is too small to analyse quantitatively.

\subsection{Dimensions of Dolomite Bodies}

The width of dolomite bodies within both the Montaña Beds and Picos de Europa Formation show lognormal distributions (validated by chi-squared test at $95 \%$ confidence level) with mean values of $9 \mathrm{~m}$ and $8 \mathrm{~m}$ for dolomites within the Montaña Beds and Picos de Europa Formation, respectively (Figure 10). About $90 \%$ of the dolomite bodies within the Montaña Beds are less than $20 \mathrm{~m}$ wide, whereas $90 \%$ of the dolomite bodies in the Picos de Europa Formation are less than $15 \mathrm{~m}$ wide. The majority of dolomite bodies both within the Montaña Beds (about 83\%) and the Picos de Europa Formation (about 88\%) are 0 to $30 \mathrm{~m}$ long. The dolomite body length data show lognormal distributions (validated by chi-squared test at $95 \%$ confidence level) with mean values of $20 \mathrm{~m}$ and $18 \mathrm{~m}$ for the bodies within the Montaña Beds and Picos de Europa Formation, respectively (Figure 10). Similarly, the dolomite body height data also have a lognormal distribution (validated by chi-squared test at $95 \%$ confidence level) with mean values of $14 \mathrm{~m}$ and $6 \mathrm{~m}$ in the Montaña Beds and Picos de Europa Formation, respectively. About $95 \%$ of the body height values within the Montaña Beds are less than 40 $\mathrm{m}$, whereas they are less than $15 \mathrm{~m}$ in the Picos de Europa Formation (Figure 10).

We identified a weak positive correlation between width and length of the dolomite bodies based on a coefficient of determination of 0.62 and 0.41 for the geobodies in the Montaña beds and the Picos de Europa Formation, respectively (Figure 10). The correlation indicates that dolomite body width is about one third of the dolomite body height in both stratigraphic units (Figure 10). In terms of height-length relationship, the body height within the Montaña Beds is about $70 \%$ of the length (correlation with coefficient of determination of 0.74 ), whereas in the Picos de Europa Formation, the body height is 33\% of the length (correlation with coefficient of determination of 0.48) (Figure 10).

The length axis orientations of dolomite bodies were used for structural analysis and plotted on a rose diagram, separately for the two stratigraphic units (Figure 11). The orientation of dolomite bodies hosted within the Montaña Beds show a wider distribution than those in Picos de Europa Formation. The dominant orientation of the dolomite bodies is $\mathrm{N} 110 \mathrm{E}$ in the Montaña Beds, and N 130 E in the Picos de Europa Formation.

\section{Discussion}

\subsection{Types of drones and their application in carbonate geology}

There are two main types of drones of interest in carbonate geological studies, namely fixedwing and multi-rotor systems. Both types are available at a range of prices, models, and flexibilities in terms of compatible sensor systems. However, there are certain aspects that make them in general more or less suitable for the type of geological work intended. Decision on the type of system to use should align with the research question to be answered and the terrain that is being analysed. Fixed-wing drones are more suitable to map relatively large areas ( $3 \mathrm{~km}^{2}$ per day), they generally achieve longer flight times (about 50 minutes) and are more expensive ( $£ 10,000$ or more) compared to consumer-grade multi-rotor systems. Fixedwing drones achieve typically a resolution of about $5 \mathrm{~cm}$ per pixel for a flight at about $150 \mathrm{~m}$ height (Campana, 2017) and they are generally capable of flying in higher winds than rotary systems. The most common consumer-grade drone systems are quadcopters (i.e. equipped with four propellers), and cost about $£ 2,000$ to $£ 5,000$. Larger rotary systems are available that can carry heavier payloads, such as LiDAR (Light Detection and Ranging), but these can cost up to $£ 250,000$. Compared to fixed-wing systems, the multi-rotor drones need a much 
smaller area for take off and landing, which significantly enhances their flexibility in the field, as they can take off from very irregular rocky surfaces. Their flight time is generally limited to no more than 20 minutes due to battery capacity. The multi-rotor drones have accurate positioning, a good level of automation and a high geometric resolution of data acquisition (Campana, 2017) similar to fixed-wing systems. In contrast to fixed-wing drones, they can be used for imaging vertical cliff faces in great detail (Nieminski and Graham, 2017), a critical advantage for carbonate geological field work. Hence, such drones could be used to map world class cliff outcrops such as the Guadalupe Mountains, the Miocene carbonate cliffs in Mallorca, the Amellago cliffs in Morocco, etc.

\subsection{Drones and imaging sensors in carbonate geology}

Alongside the type of platform (drone), also the type of sensor and data processing are remote sensing components that should be aligned with the research objectives. Moreover, the type of platform and sensor are interlinked, since for example heavy SLR digital cameras cannot be carried by a small, lightweight, consumer-grade drone. In our study, we used a panchromatic optical sensor, capturing the visible portion of the electromagnetic spectrum, in a 12 Mega Pixel digital camera. There are also commercially-available multispectral and hyperspectral sensors that can capture shortwave to thermal infrared and near-ultraviolet portions of the electromagnetic spectrum (Verhoeven, 2012; Verhoeven and Schmitt, 2010). In contrast, advances in active source sensors for high resolution 3D data collection mainly focus on laser scanning technologies such as LiDAR, which measures the distance to a target based on the travel time of reflected light (Bemis et al., 2014; Hodgetts, 2013). Although airborne LiDAR is possible using drones, they are currently expensive, and further developments on these systems are needed to miniaturise them as suitable payloads for lowcost platforms.

\subsection{Practicality of using drones in geological surveys}

Obtaining detailed maps of 3D models from surveys of sedimentological, diagenetic and structural study sites can be a key component in carbonate geological research, and provide the fundament for further analysis. In the past, such research focused mainly on selected sites, documenting features manually, and was labour intensive. Developments in GPS-based surveys and subsequently laser scanning methods have greatly improved accuracy, precision, and extent of mapping. Laser scanning techniques are, however, still time consuming, expensive, and restricted by environmental and field conditions (visibility, morphology, etc). The advance of extraordinarily fast, cost-effective and high geometric resolution aerial photogrammetry using small drones is revolutionary compared to the traditional methods. Quantitative measurements on 3D models constructed from drone surveys have greater repeatability than those from outcrops, are collected in only a fraction of the time, and enable volumetric measurements (Chesley et al., 2017). Moreover, using the drones for field surveys is very flexible and practical. The small drone that we used in our study is lightweight and can be easily carried by one person in the field, which makes it ideal in terms of mobility for mapping areas in mountainous regions, such as the Picos de Europa, which require long daily hikes to gain access. Furthermore, one can deploy a drone at short notice, and at a wide range of times and localities, which presents major advantages over the hire of a traditional light aircraft or helicopter. Legislation on drone use, however, is evolving, and needs some investigation when flying the drone, especially as local rules may differ by country or district. Restrictions generally apply in terms of flight height, no-fly zones, and permission from air traffic control. Drone regulations in Spain are strict and prohibit flying a drone more than 100 $\mathrm{m}$ high or above stadiums, streets, concerts, any political building, beaches, cathedrals, etc. One needs a license to use the drone and has to be at least 18 years old to be legally able to fly it. To give an example from another country, the Civil Aviation Authority UK Dronecode involves the following: 1) always keep your drone in sight, 2) keep your drone below 120m height, 3) follow the manufacturer's instructions, 4) keep $50 \mathrm{~m}$ distance from people and properties and $150 \mathrm{~m}$ distance from crowds and built up areas, 5) legal responsibility lies with the drone operator, and 6) stay well away from aircrafts, airports and airfields. If one wishes 
to fly the drone closer to buildings and crowds, then permission from the CAA needs to be obtained, similar to that required by drone operators who conduct commercial flights. Finally, drone aerial photogrammetry fills a real gap in effective spatial scale and resolution between that of manual field mapping or ground-based LiDAR and that of traditional airborne higheraltitude methods.

\subsection{Applying drone aerial photogrammetry for mapping of dolomite geobodies}

The application of drone based remote sensing is an innovative way to map diagenetic geobodies. In only seven days of survey, we mapped a total area of $3.7 \mathrm{~km}^{2}$ by drone remote sensing in mountainous terrain. One could achieve larger areal coverage depending on greater availability of batteries, selection of a less mountainous area requiring less daily hiking, or the use of a different type of drone (although heavier platforms would be less practical when significant hiking is needed). Also the extent of the coverage is linked to the targeted resolution. However, in mountainous regions, the maximum resolution will depend on the topography and extent of area to be captured in one flight. In our study, we acquired models with a resolution of $5 \mathrm{~cm}$ to $25 \mathrm{~cm}$, which is comparable to the resolution of airborne LiDARbased models, with typical accuracy of up to $20 \mathrm{~cm}$ (Jones et al., 2010). Processing time depends strongly on the number of photos, coverage area of study, the user-defined processing quality, and the performance of computers that will be used for creating the DSMs and orthomosaic (i.e. a standard consumer-grade laptop took about 24 hours to process the full model).

Besides the highlighted advantages and opportunities of using a small drone for mapping geological features, the following two aspects are more challenging. First, the presence of vegetation on the surface may compromise slightly the accuracy of the data collected. Depending on the type of vegetation, information on the rock underneath can still be collected by manual survey or by the use of a laser scanning technique. Also, point cloud processing software of greater sophistication than used in our study (such as CloudCompare) allows manual editing and rendering of 3D point clouds and triangular meshes with advanced processing algorithms, which may be helpful in taking account of vegetation cover. LiDAR collects a 3D point location with a single pulse of light that collects ground surface points as long as the pulse of light can pass through the vegetation (Bemis et al., 2014). LiDAR derived 3D models have been used in previous studies to characterize dolomite bodies, for example in the Latemar Platform, Italy (Jacquemyn et al., 2015), and the Zagros Mountains, Iran (Lapponi et al., 2011). However, LiDAR systems are at this time still too heavy and too costly to be used on small drones. In our study, uncertainty in dolomite presence in a small part of the model is predominantly caused by the occurrence of snow patches or vegetation cover. Nevertheless, the extreme high definition is rarely necessary, and therefore, the real need for LiDAR is fairly limited. Second, although volumetric measurements can be made directly from the model and are helpful for estimating resources in analogue subsurface reservoir models (Chesley et al., 2017), the drone based 3D model represents what we observe at the surface, but does not provide subsurface information that could be derived from seismic imaging, for example. In many cases, geoscientists, and in particular sedimentary geologists, aim for an understanding of the 3D geometry of the geobodies that extend into the subsurface. The fact that we can only delineate the rims of the dolomite bodies at the surface remains a limitation and represents uncertainty in the reconstruction of dolomite body dimensions, even though the irregularity of the topography presents an advantage in determining 3D dimensions. As a consequence, the reported data on dolomite body dimensions should be interpreted as minimum dimensions.

Despite these challenges, drone based remote sensing has proven to be very effective for the mapping of dolomite geobodies, and this method could offer many other opportunities for geological research. Further improvement in our method could develop semi-automated dolomite body mapping, similar to semi-automatic interpretation developed for mapping other geological structures (Vasuki et al., 2014). In addition, further developments could focus on 
the application of other types of sensors such as hyperspectral imaging and the use of texture mapping (Beckert et al., 2017; Kurz et al., 2012). Moreover, the DSM from drone mapping could also be integrated with data from other sources, potentially using near-surface geophysical surveys such as ground-penetrating radar (GPR). GPR offers 3D geometrical representations of subsurface geological horizons (Fernandes et al., 2015), such as those at the contact of boundaries of dolomite bodies. Combination of the DSM and a 3D GPR dataset may allow identification of the 3D geometry of dolomite bodies and their degree of connectivity. A previous study of GPR gave promising results, where the method generated images of stratabound dolomite bodies (Tsoflias and Becker, 2008).

\subsection{Spatial distribution and dimensions of dolomite geobodies controlled by strike-slip faults}

The detailed map of the distribution of the dolomite bodies in the study area shows that the these geobodies are not regularly or randomly distributed, but rather occur in a clustering pattern, in particular those hosted in the Montaña Beds. An analysis of dolomite body proximity to faults reveals that there is a strong structural control on the spatial distribution of dolomite bodies. Despite the lack of correlation between the thrust faults and dolomite bodies, the geobodies are generally more abundant close to the nearby strike-slip faults. This link reveals, importantly, the predominant control of strike-slip faults on dolomitization, rather than thrust faults in the study area, and is in agreement with interpretations of the common association of hydrothermal dolomite with extensional or strike-slip faults by Davies and Smith (2006).

The results indicate that the geometry of dolomite bodies is probably not strongly controlled by the limestone host rock lithology (except for minor control on the irregular dolomite boundary at decimeter scale), since the dolomite bodies cut through limestone beds. This interpretation is consistent with other dolomite body geometry studies in which it was demonstrated that there is no distinct link between the host rock limestone texture and the extent of the fault-related dolomite body away from the fault into the host rock (Vandeginste et al., 2013). Analysis of comparison between dolomite bodies across regions indicates that the general dolomite body dimensions probably relate to the permeability of the host rock limestone at the time of dolomitization, or to the source and fluid flow driving mechanisms for dolomitizing fluids (Vandeginste et al., 2014; Wilson et al., 2007). The dimensions (width, length, and height) of dolomite bodies in the study area range from a few meters to about 200 $\mathrm{m}$. The length/width ratio of the dolomite bodies is on average about 3, similar to that for dolomite bodies documented in the southern part of the Picos de Europa unit (Vandeginste et al., 2015b). The length orientation of the dolomite bodies seems to be strongly controlled by structural features. In the study area, the dominant orientation of the dolomite body length axis is sub-parallel to the orientation of strike-slip faults (NNW-SSE to NW-SE), reinforcing the identified link between the distribution of dolomite bodies and strike-slip faults (preferentially over thrust faults).

Generally, the dolomite bodies located near the San Carlos fault are larger than those located near the Middle and Northern Fault (Figure 9). The difference in length and width of dolomite bodies can be interpreted as the difference in the strain magnitude of nearby strike-slip fault zones. Fault zones commonly consist of a fault core and an associated damage zone that is mechanically related to the growth of the fault zone (Billi et al., 2003; Caine et al., 1996; PutzPerrier and Sanderson, 2008). The damage zone is composed of a volume of rock affected by fault-related fracturing (Billi et al., 2003). The fact that, according to the geological map of the study area, the length of San Carlos Fault is significantly larger or has a higher strain magnitude than the Middle Fault and the Northern Fault, suggests that the San Carlos Fault may have generated an associated fracture network within its damage zone with a higher fracture density, and a larger aperture of fractures, compared to the other faults in the study area. Fault damage zones with higher fracture density or larger aperture of fractures probably acted as preferential conduits for dolomitizing fluids and, as a consequence, generated larger dolomite bodies. Further evidence of fluid flow along fault zones is derived from the microscopic and fluid inclusion data indicating that relatively warm, highly saline fluids formed 
discordant bodies of fabric-destructive coarse dolomite (Gomez-Fernandez et al., 2000; Racine, 2017; Vandeginste et al., 2015b). Hydrothermal dolomitization has also been documented in Carboniferous host limestone in the Bodón unit of Cantabria (Gasparrini et al., 2006; Lapponi et al., 2014), southwest of the study area.

\subsection{Future developments in drone based remote sensing}

Despite the major advances in drone based remote sensing capabilities and flexibility, there is still ample room for improvement. Technical developments are still needed to extend flight times of the small platforms, increase their lifting capacity and improve flexibility of the software. The most recent small platforms have seen major improvement in advanced collision detection already. Another challenge is that the small drones are affected by strong winds, which makes them significantly weather dependent. In current systems, terrestrial laser scanning still provides higher resolution data and more consistency compared to the droneSfM method (Wilkinson et al., 2016). Greater diversity and more revolutionary opportunities will result from further advances in lightweight sensors that can measure and analyse nonvisible portions of the electromagnetic spectrum, such as infrared and hyperspectral imaging, and lightweight, cost-effective LiDAR systems.

\section{Conclusions}

The use of drones with SfM photogrammetry offers the opportunity to build 3D models from geometrically complex or critical rock exposures. The method is particularly powerful to collect data from outcrops that are inaccessible or unsafe to access by foot, providing the possibility to build large quantitative data sets. The limited infrastructure requirements and resulting greater portability and decreased cost enable the reconstruction of photo-based high resolution 3D geospatial data at relatively low cost and expertise, and relatively quickly. Drone aerial photogrammetry is especially useful to bridge a real gap in effective spatial scale and resolution between that of manual field mapping or terrestrial laser scanning and that of traditional airborne higher-altitude methods.

The method explained in this paper illustrates how we can characterize diagenetic geobodies in an effective way at subseismic scale with appropriate accuracy using high resolution drone captured images in carbonate geological studies. The results of our study indicate that the dolomite geobodies preferentially occur near to strike-slip faults, rather than thrust faults or types of host rock limestone lithology in the study area. Importantly, the dolomite geobody distribution and orientation can be plausibly related to the strain magnitude of the strike-slip faults. We propose that these links and controls may be applicable more generally to structurally-controlled dolomitization.

Further developments in drone based remote sensing are still needed to improve flight time, lifting capacity, software flexibility and greater range of lightweight sensors. Advances on these fronts will enable further revolutionary opportunities not only in geological research, but also in a wide range of other disciplines.

\section{Acknowledgements}

We would like to thank Qatar Petroleum, Shell and the Qatar Science and Technology Park for funding fieldwork in the Picos de Europa, Spain. The first author is also very grateful to Indonesia Endowment Fund for Education (LPDP) for their financial support during his study at Imperial College London. We thank Fergus Kennedy and Manuel Antonio Diaz Rodriguez for conducting the drone flights and help with image processing. The director of the National Park of Picos de Europa is acknowledged for permission to conduct this research. C Jordan publishes with permission of the Executive Director of the British Geological Survey. We are grateful to the reviewers, Aurelien Pierre and an anonymous reviewer, for their positive and constructive comments, and to Alex MacNeil for editorial efforts and ensuring an effective review process. 


\section{Appendix A. Supplementary data}

\section{References}

Anderson, K., Gaston, K.J., 2013. Lightweight unmanned aerial vehicles will revolutionize spatial ecology. Frontiers in Ecology and the Environment 11, 138-146.

Arndt, M., Virgo, S., Cox, S.F., Urai, J.L., 2014. Changes in fluid pathways in a calcite vein mesh (Natih Formation, Oman Mountains): insights from stable isotopes. Geofluids 14, 391-418.

Bahamonde, J.R., Vera, C., Colmenero, J.R., 2000. A steep-fronted Carboniferous carbonate platform: clinoformal geometry and lithofacies (Picos de Europa, NW Spain). Sedimentology 47, 645-664.

Bandini, F., Jakobsen, J., Olesen, D., Reyna-Gutierrez, J.A., Bauer-Gottwein, P., 2017. Measuring water level in rivers and lakes from lightweight Unmanned Aerial Vehicles. Journal of Hydrology 548, 237250.

Beckert, J., Vandeginste, V., John, C.M., 2015. Exploring the geological features and processes that control the shape and internal fabrics of late diagenetic dolomite bodies (Lower Khuff equivalent Central Oman Mountains). Marine and Petroleum Geology 68, 325-340.

Beckert, J., Vandeginste, V., McKean, T.J., Alroichidi, A., John, C.M., 2017. Ground-based hyperspectral imaging as a tool to identify different carbonate phases in natural cliffs. International Journal of Remote Sensing.

Beckert, J., Vandeginste, V., McKean, T.J., Alroichidi, A., John, C.M., 2018. Ground-based hyperspectral imaging as a tool to identify different carbonate phases in natural cliffs. International Journal of Remote Sensing in print.

Bemis, S.P., Micklethwaite, S., Turner, D., James, M.R., Akciz, S., Thiele, S.T., Bangash, H.A., 2014. Ground-based and UAV-Based photogrammetry: A multi-scale, high-resolution mapping tool for structural geology and paleoseismology. Journal of Structural Geology 69, 163-178.

Bhardwaj, A., Sam, L., Akanksha, Martin-Torres, F.J., Kumar, R., 2016. UAVs as remote sensing platform in glaciology: Present applications and future prospects. Remote Sensing of Environment 175, 196204.

Billi, A., Storti, F., Salvini, F., 2003. Particle size distributions of fault rocks and fault transpression: are they related? Terra Nova 15, 61-66.

Bistacchi, A., Balsamo, F., Storti, F., Mozafari, M., Swennen, R., Solum, J., Tueckmantel, C., Taberner, C., 2015. Photogrammetric digital outcrop reconstruction, visualization with textured surfaces, and three-dimensional structural analysis and modeling: Innovative methodologies applied to faultrelated dolomitization (Vajont Limestone, Southern Alps, Italy). Geosphere 11, 2031-2048.

Bodin, S., Mattioli, E., Froehlich, S., Marshall, J.D., Boutib, L., Lahsini, S., Redfern, J., 2010. Toarcian carbon isotope shifts and nutrient changes from the Northern margin of Gondwana (High Atlas, Morocco, Jurassic): Palaeoenvironmental implications. Palaeogeography Palaeoclimatology Palaeoecology 297, 377-390.

Budd, D.A., Frost, E.L., III, Huntington, K.W., Allwardt, P.F., 2013. Syndepositional deformation features in high-relief carbonate platforms: long-lived conduits for diagenetic fluids. Journal of Sedimentary Research 83, 14-38.

Caine, J.S., Evans, J.P., Forster, C.B., 1996. Fault zone architecture and permeability structure. Geology 24, 1025-1028.

Campana, S., 2017. Drones in Archaeology. State-of-the-art and Future Perspectives. Archaeological Prospection.

Caturegli, L., Corniglia, M., Gaetani, M., Grossi, N., Magni, S., Migliazzi, M., Angelini, L., Mazzoncini, M., Silvestri, N., Fontanelli, M., Raffaelli, M., Peruzzi, A., Volterrani, M., 2016. Unmanned Aerial Vehicle to Estimate Nitrogen Status of Turfgrasses. Plos One 11.

Chesley, J.T., Leier, A.L., White, S., Torres, R., 2017. Using unmanned aerial vehicles and structurefrom-motion photogrammetry to characterize sedimentary outcrops: An example from the Morrison Formation, Utah, USA. Sedimentary Geology 354, 1-8. 
Davies, G.R., Smith, L.B., Jr., 2006. Structurally controlled hydrothermal dolomite reservoir facies: An overview. AAPG Bulletin 90, 1641-1690.

De Michele, C., Avanzi, F., Passoni, D., Barzaghi, R., Pinto, L., Dosso, P., Ghezzi, A., Gianatti, R., Della Vedova, G., 2016. Using a fixed-wing UAS to map snow depth distribution: an evaluation at peak accumulation. Cryosphere 10, 511-522.

De Reu, J., Trachet, J., Laloo, P., De Clercq, W., 2016. From Low Cost UAV Survey to High Resolution Topographic Data: Developing our Understanding of a Medieval Outport of Bruges. Archaeological Prospection 23, 335-346.

Dewit, J., Huysmans, M., Muchez, P., Hunt, D.W., Thurmond, J.B., Verges, J., Saura, E., Fernandez, N., Romaire, I., Esestime, P., Swennen, R., 2012. Reservoir characteristics of fault-controlled hydrothermal dolomite bodies: Ramales Platform case study, in: Garland, J., Neilson, J.E., Laubach, S.E., Whidden, K.J. (Eds.), Advances in Carbonate Exploration and Reservoir Analysis. Geological Society, London, Special Publications, London.

Ehrenberg, S.N., Nadeau, P.H., 2005. Sandstone vs. carbonate petroleum reservoirs: A global perspective on porosity-depth and porosity-permeability relationships. Aapg Bulletin 89, 435-445.

Faye, E., Rebaudo, F., Yanez-Cajo, D., Cauvy-Fraunie, S., Dangles, O., 2016. A toolbox for studying thermal heterogeneity across spatial scales: from unmanned aerial vehicle imagery tolandscape metrics. Methods in Ecology and Evolution 7, 437-446.

Fernandes, A.L., Medeiros, W.E., Bezerra, F.H.R., Oliveira, J.G., Cazarin, C.L., 2015. GPR investigation of karst guided by comparison with outcrop and unmanned aerial vehicle imagery. Journal of Applied Geophysics 112, 268-278.

Flynn, K.F., Chapra, S.C., 2014. Remote Sensing of Submerged Aquatic Vegetation in a Shallow NonTurbid River Using an Unmanned Aerial Vehicle. Remote Sensing 6, 12815-12836.

Fontana, S., Nader, F.H., Morad, S., Ceriani, A., Al-Aasm, I.S., 2010. Diagenesis of the Khuff Formation (Permian-Triassic), northern United Arab Emirates. Arabian Journal of Geosciences 3, 351-368.

Garcia, E.M., Marquinez, J., Heredia, N., Navaro, D., Trodriguez-Fernandez, L.R., 1977. Mapa Geológico de la Región Careña-Cabrales, scale 1:50,000. Instituto Geológico y Minero de España.

Gasparrini, M., Bechstadt, T., Boni, M., 2006. Massive hydrothermal dolomites in the southwestern Cantabrian Zone (Spain) and their relation to the Late Variscan evolution. Marine and Petroleum Geology 23, 543-568.

Gomez-Fernandez, F., Both, R.A., Mangas, J., Arribas, A., 2000. Metallogenesis of Zn-Pb carbonatehosted mineralization in the southeastern region of the Picos de Europa (central northern Spain) province: Geologic, fluid inclusion, and stable isotope studies. Economic Geology and the Bulletin of the Society of Economic Geologists 95, 19-39.

Hird, J.N., Montaghi, A., McDermid, G.J., Kariyeva, J., Moorman, B.J., Nielsen, S.E., McIntosh, A.C.S., 2017. Use of Unmanned Aerial Vehicles for Monitoring Recovery of Forest Vegetation on Petroleum Well Sites. Remote Sensing 9.

Hodgetts, D., 2013. Laser scanning and digital outcrop geology in the petroleum industry: A review. Marine and Petroleum Geology 46, 335-354.

Homewood, P., Razin, P., Grelaud, C., Droste, H., Vahrenkamp, V., Mettraux, M., Mattner, J., 2008. Outcrop sedimentology of the Natih Formation, northern Oman: A field guide to selected outcrops in the adam foothills and Al Jabal al Akhdar areas. Geoarabia 13, 39-120.

Jacquemyn, C., Huysmans, M., Hunt, D., Casini, G., Swennen, R., 2015. Multi-scale three-dimensional distribution of fracture- and igneous intrusion-controlled hydrothermal dolomite from digital outcrop model, Latemar platform, Dolomites, northern Italy. Aapg Bulletin 99, 957-984.

Jakob, S., Zimmermann, R., Gloaguen, R., 2017. The Need for Accurate Geometric and Radiometric Corrections of Drone-Borne Hyperspectral Data for Mineral Exploration: MEPHySToA Toolbox for PreProcessing Drone-Borne Hyperspectral Data. Remote Sensing 9.

Jones, T.G., Coops, N.C., Sharma, T., 2010. Assessing the utility of airborne hyperspectral and LiDAR data for species distribution mapping in the coastal Pacific Northwest, Canada. Remote Sensing of Environment 114, 2841-2852. 
Jordan, C.J., Napier, B., 2016. Developing digital fieldwork technologies at the British Geological Survey, in: Bowman, M., Smyth, H.R., Good, T.R., Passey, S.R., Hirst, J.P.P., Jordan, C.J. (Eds.), Value of Outcrop Studies in Reducing Subsurface Uncertainty and Risk in Hydrocarbon Exploration and Production, pp. 219-229.

Kerans, C., Zahm, C., Garcia-Fresca, B., Harris, P., 2017. Guadalupe Mountains, West Texas and New Mexico: Key excursions. Aapg Bulletin 101, 465-474.

Kurz, T.H., Dewit, J., Buckley, S.J., Thurmond, J.B., Hunt, D.W., Swennen, R., 2012. Hyperspectral image analysis of different carbonate lithologies (limestone, karst and hydrothermal dolomites): the Pozalagua Quarry case study (Cantabria, North-west Spain). Sedimentology 59, 623-645.

Lapponi, F., Bechstadt, T., Boni, M., Banks, D.A., Schneider, J., 2014. Hydrothermal dolomitization in a complex geodynamic setting (Lower Palaeozoic, northern Spain). Sedimentology 61, 411-443.

Lapponi, F., Casini, G., Sharp, I., Blendinger, W., Fernandez, N., Romaire, I., Hunt, D., 2011. From outcrop to 3D modelling: a case study of a dolomitized carbonate reservoir, Zagros Mountains, Iran. Petroleum Geoscience 17, 283-307.

Masek, J.G., Hayes, D.J., Hughes, M.J., Healey, S.P., Turner, D.P., 2015. The role of remote sensing in process-scaling studies of managed forest ecosystems. Forest Ecology and Management 355, 109-123. Mateos, R.M., Azanon, J.M., Roldan, F.J., Notti, D., Perez-Pena, V., Galve, J.P., Perez-Garcia, J.L., Colomo, C.M., Gomez-Lopez, J.M., Montserrat, O., Devantery, N., Lamas-Fernandez, F., FernandezChacon, F., 2017. The combined use of PSInSAR and UAV photogrammetry techniques for the analysis of the kinematics of a coastal landslide affecting an urban area (SE Spain). Landslides 14, 743-754.

Merino-Tome, O., Della Porta, G., Pierre, A., Kenter, J.A.M., Durlet, C., Verwer, K., 2017. Intact seismicscale platforms and ramps in the Lower to Middle Jurassic of Morocco: Implications for stratal anatomy and lithofacies partitioning. Aapg Bulletin 101, 505-513.

Merino-Tome, O.A., Bahamonde, J.R., Colmenero, J.R., Heredia, N., Villa, E., Farias, P., 2009. Emplacement of the Cuera and Picos de Europa imbricate system at the core of the Iberian-Armorican arc (Cantabrian zone, north Spain): New precisions concerning the timing of arc closure. Geological Society of America Bulletin 121, 729-751.

Mlambo, R., Woodhouse, I.H., Gerard, F., Anderson, K., 2017. Structure from Motion (SfM) Photogrammetry with Drone Data: A Low Cost Method for Monitoring Greenhouse Gas Emissions from Forests in Developing Countries. Forests 8.

Nieminski, N.M., Graham, S.A., 2017. Modeling stratigraphic architecture using small unmanned aerial vehicles and photogrammetry: examples from the Miocene East Coast Basin, New Zealand. Journal of Sedimentary Research 87, 126-132.

Nishar, A., Richards, S., Breen, D., Robertson, J., Breen, B., 2016. Thermal infrared imaging of geothermal environments and by an unmanned aerial vehicle (UAV): A case study of the Wairakei Tauhara geothermal field, Taupo, New Zealand. Renewable Energy 86, 1256-1264.

Ouedraogo, M.M., Degre, A., Debouche, C., Lisein, J., 2014. The evaluation of unmanned aerial systembased photogrammetry and terrestrial laser scanning to generate DEMs of agricultural watersheds. Geomorphology 214, 339-355.

Padua, L., Vanko, J., Hruska, J., Adao, T., Sousa, J.J., Peres, E., Morais, R., 2017. UAS, sensors, and data processing in agroforestry: a review towards practical applications. International Journal of Remote Sensing 38, 2349-2391.

Paneque-Galvez, J., McCall, M.K., Napoletano, B.M., Wich, S.A., Koh, L.P., 2014. Small Drones for Community-Based Forest Monitoring: An Assessment of Their Feasibility and Potential in Tropical Areas. Forests 5, 1481-1507.

Puliti, S., Orka, H.O., Gobakken, T., Naesset, E., 2015. Inventory of Small Forest Areas Using an Unmanned Aerial System. Remote Sensing 7, 9632-9654.

Putz-Perrier, M.W., Sanderson, D.J., 2008. Spatial distribution of brittle strain in layered sequences. Journal of Structural Geology 30, 50-64. 
Racine, T., 2017. Characterising the dolostone host of an MVT Zn-Pb deposit in the Picos de Europa mining district (NW Spain): optical mineralogy, geochemical and fluid inclusion studies, Department of Earth Science and Engineering. Imperial College London, London, p. 58.

Sanders, K.T., Masri, S.F., 2016. The energy-water agriculture nexus: the past, present and future of holistic resource management via remote sensing technologies. Journal of Cleaner Production 117, 73-88.

Sankey, T., Donager, J., McVay, J., Sankey, J.B., 2017. UAV lidar and hyperspectral fusion for forest monitoring in the southwestern USA. Remote Sensing of Environment 195, 30-43.

Schrod, J., Weber, D., Drucke, J., Keleshis, C., Pikridas, M., Ebert, M., Cvetkovic, B., Nickovic, S., Marinou, E., Baars, H., Ansmann, A., Vrekoussis, M., Mihalopoulos, N., Sciare, J., Curtius, J., Bingemer, H.G., 2017. Ice nucleating particles over the Eastern Mediterranean measured by unmanned aircraft systems. Atmospheric Chemistry and Physics 17, 4817-4835.

Seitz, A.R., Nanez, J.E., Holloway, S.R., Watanabe, T., 2006. Perceptual Learning of Motion Leads to Faster Flicker Perception. Plos One 1.

Serban, G., Rus, I., Vele, D., Bretcan, P., Alexe, M., Petrea, D., 2016. Flood-prone area delimitation using UAV technology, in the areas hard-to-reach for classic aircrafts: case study in the north-east of Apuseni Mountains, Transylvania. Natural Hazards 82, 1817-1832.

Sharp, I., Gillespie, P., Morsalnezhad, D., Taberner, C., Karpuz, R., Verges, J., Horbury, A., Pickard, N., Garland, J., Hunt, D., 2010. Stratigraphic architecture and fracture-controlled dolomitization of the Cretaceous Khami and Bangestan groups: an outcrop case study, Zagros Mountains, Iran, in: Van Buchem, F.S.P., Gerdes, K.D., Esteban, M. (Eds.), Mesozoic and Cenozoic Carbonate Systems of the Mediterranean and the Middle East: Stratigraphic and Diagenetic Reference Models, pp. 343-396.

Snavely, N., Seitz, S.M., Szeliski, R., 2008. Modeling the world from Internet photo collections. International Journal of Computer Vision 80, 189-210.

Spence, C., Mengistu, S., 2016. Deployment of an unmanned aerial system to assist in mapping an intermittent stream. Hydrological Processes 30, 493-500.

Tamminga, A.D., Eaton, B.C., Hugenholtz, C.H., 2015. UAS-based remote sensing of fluvial change following an extreme flood event. Earth Surface Processes and Landforms 40, 1464-1476.

Tang, L.N., Shao, G.F., 2015. Drone remote sensing for forestry research and practices. Journal of Forestry Research 26, 791-797.

Tong, X.H., Liu, X.F., Chen, P., Liu, S.J., Luan, K.F., Li, L.Y., Liu, S., Liu, X.L., Xie, H., Jin, Y.M., Hong, Z.H., 2015. Integration of UAV-Based Photogrammetry and Terrestrial Laser Scanning for the ThreeDimensional Mapping and Monitoring of Open-Pit Mine Areas. Remote Sensing 7, 6635-6662.

Tsoflias, G.P., Becker, M.W., 2008. Ground-penetrating-radar response to fracture-fluid salinity: Why lower frequencies are favorable for resolving salinity changes. Geophysics 73, J25-J30.

Vandeginste, V., John, C.M., 2012. Influence of climate and dolomite composition on dedolomitization: insights from a multi-proxy study in the central Oman Mountains. Journal of Sedimentary Research 82, 177-195.

Vandeginste, V., John, C.M., Beckert, J., 2015a. Diagenetic Geobodies: Fracture-Controlled Burial Dolomite in Outcrops From Northern Oman. SPE Reservoir Evaluation \& Engineering 18, 84-93.

Vandeginste, V., John, C.M., Cosgrove, J.W., Manning, C., 2014. Dimensions, texture-distribution and geochemical heterogeneities of fracture-related dolomite geobodies hosted in Ediacaran limestone, northern Oman. AAPG Bulletin 98, 1789-1809.

Vandeginste, V., John, C.M., van de Flierdt, T., Cosgrove, J.W., 2013. Linking process, dimension, texture and geochemistry in dolomite geobodies: a case study from Wadi Mistal (northern Oman). AAPG Bulletin 97, 1181-1207.

Vandeginste, V., Rafiuddin, N.L., Peskin, A., 2015b. Three-dimensional reconstruction of diagenetic geobodies for geological carbon dioxide storage. International Journal of Greenhouse Gas Control 42, 319-328. 
Vandeginste, V., Swennen, R., Gleeson, S.A., Ellam, R.M., Osadetz, K., Roure, F., 2005. Zebra dolomitization as a result of focused fluid flow in the Rocky Mountains Fold and Thrust Belt, Canada. Sedimentology 52, 1067-1095.

Vasuki, Y., Holden, E.J., Kovesi, P., Micklethwaite, S., 2014. Semi-automatic mapping of geological Structures using UAV-based photogrammetric data: An image analysis approach. Computers \& Geosciences 69, 22-32.

Ventura, D., Bruno, M., Lasinio, G.J., Belluscio, A., Ardizzone, G., 2016. A low-cost drone based application for identifying and mapping of coastal fish nursery grounds. Estuarine Coastal and Shelf Science 171, 85-98.

Verhoeven, G.J., 2012. Near-Infrared Aerial Crop Mark Archaeology: From its Historical Use to Current Digital Implementations. Journal of Archaeological Method and Theory 19, 132-160.

Verhoeven, G.J., Schmitt, K.D., 2010. An attempt to push back frontiers - digital near-ultraviolet aerial archaeology. Journal of Archaeological Science 37, 833-845.

Watts, A.C., Ambrosia, V.G., Hinkley, E.A., 2012. Unmanned Aircraft Systems in Remote Sensing and Scientific Research: Classification and Considerations of Use. Remote Sensing 4, 1671-1692.

Weil, A.B., Gutierrez-Alonso, G., Johnston, S.T., Pastor-Galan, D., 2013. Kinematic constraints on buckling a lithospheric-scale orocline along the northern margin of Gondwana: A geologic synthesis. Tectonophysics 582, 25-49.

Westoby, M.J., Brasington, J., Glasser, N.F., Hambrey, M.J., Reynolds, J.M., 2012. 'Structure-fromMotion' photogrammetry: A low-cost, effective tool for geoscience applications. Geomorphology 179, 300-314.

Westoby, M.J., Dunning, S.A., Woodward, J., Hein, A.S., Marrero, S.M., Winter, K., Sugden, D.E., 2015. Sedimentological characterization of Antarctic moraines using UAVs and Structure-from-Motion photogrammetry. Journal of Glaciology 61, 1088-1102.

Wilkinson, M.W., Jones, R.R., Woods, C.E., Gilment, S.R., McCaffrey, K.J.W., Kokkalas, S., Long, J.J., 2016. A comparison of terrestrial laser scanning and structure-from-motion photogrammetry as methods for digital outcrop acquisition. Geosphere 12, 1865-1880.

Wilson, M.E.J., Evans, M.J., Oxtoby, N.H., Nas, D.S., Donnelly, T., Thirlwall, M., 2007. Reservoir quality, textural evolution and origin of fault-associated dolomites. AAPG Bulletin 91, 1247-1272.

Yang, C.H., Westbrook, J.K., Suh, C.P.C., Martin, D.E., Hoffmann, W.C., Lan, Y.B., Fritz, B.K., Goolsby, J.A., 2014. An Airborne Multispectral Imaging System Based on Two Consumer-Grade Cameras for Agricultural Remote Sensing. Remote Sensing 6, 5257-5278. 


\section{Figure Captions}

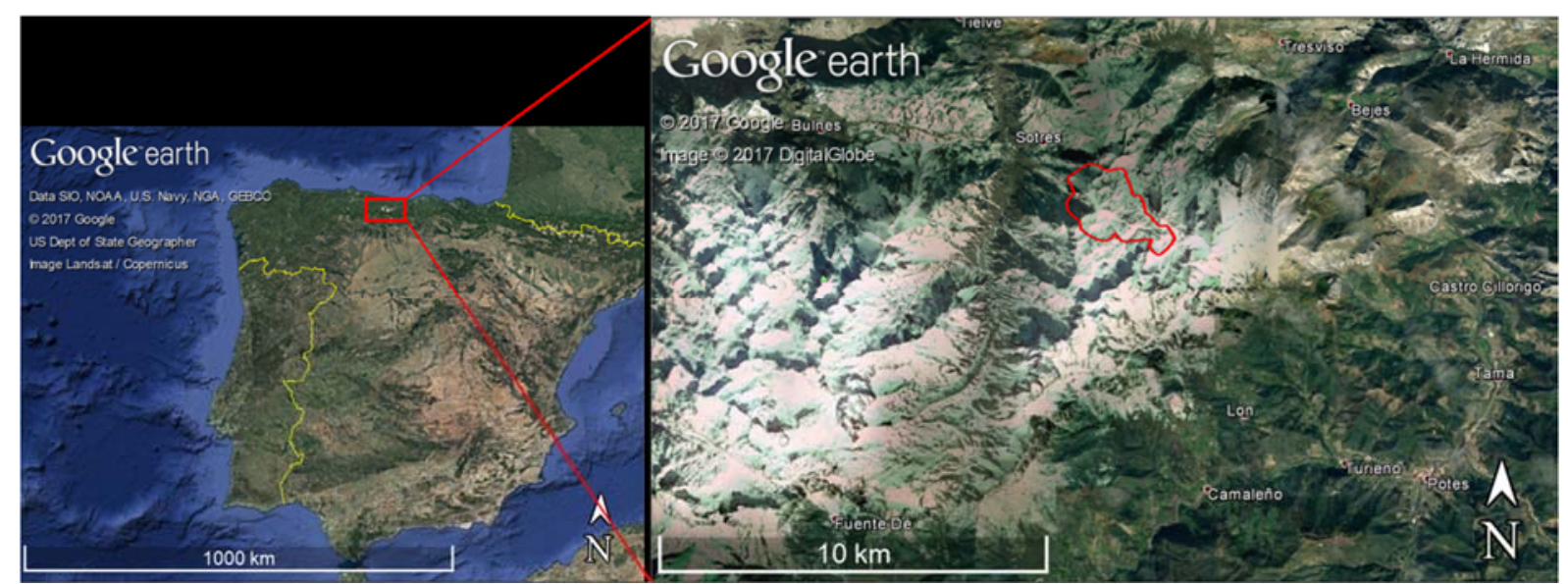

Figure 1. Location of the study area as indicated by the red polygon. Google Earth maps.

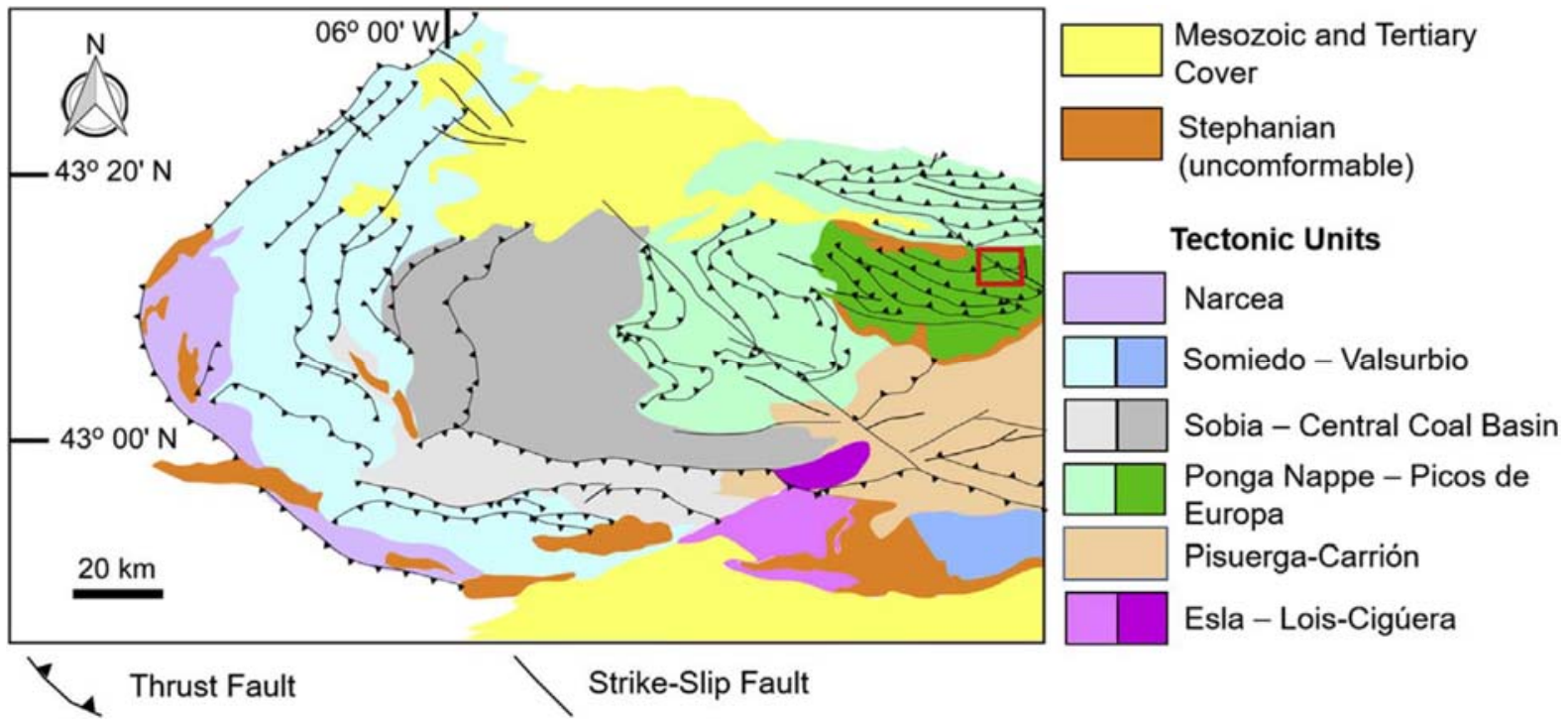

Figure 2. Simplified tectonic unit map of the Cantabrian zone. The study area is location within the Picos de Europa unit as highlighted by the red rectangle in the figure (modified after Weil et al., 2013). 


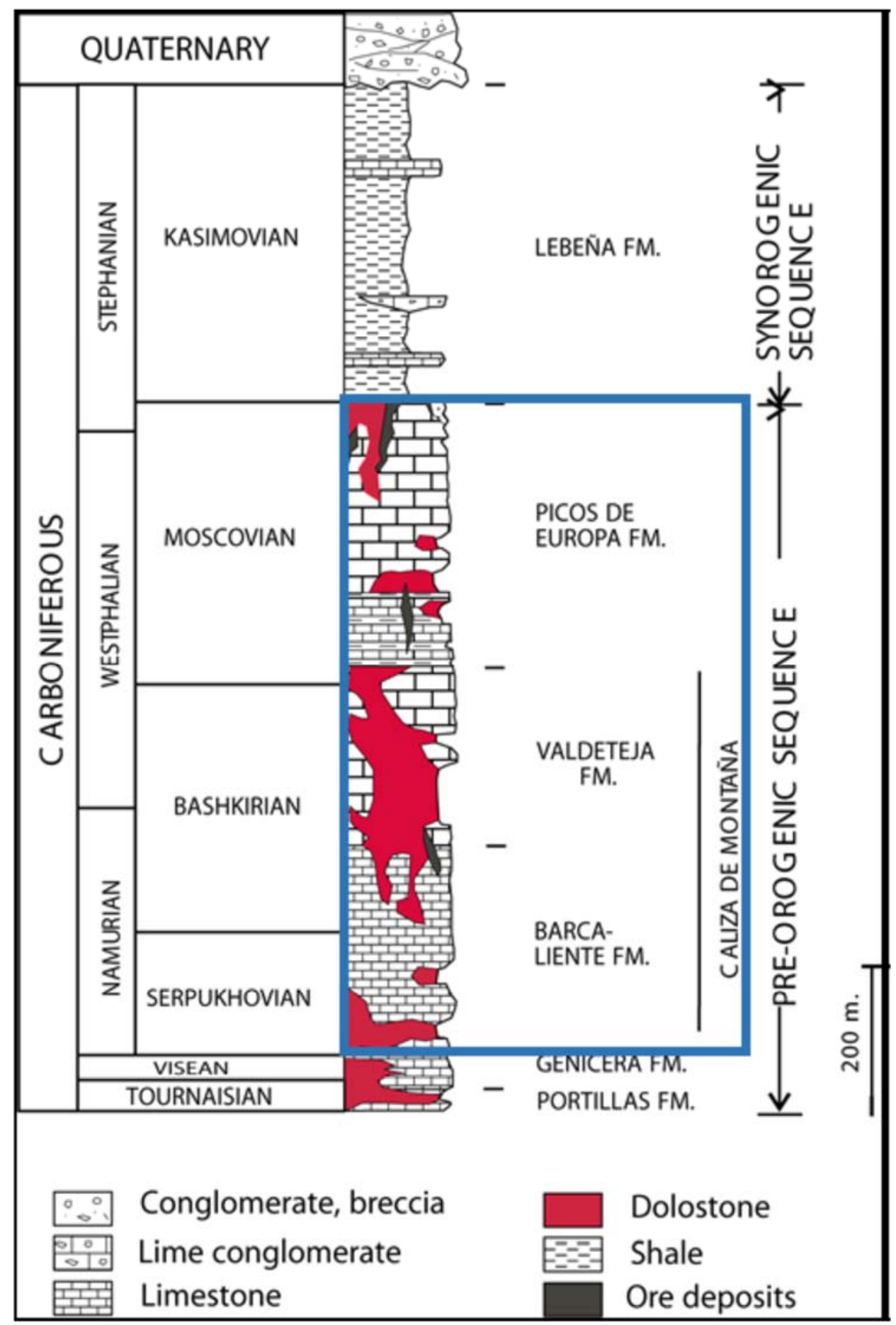

Figure 3. Stratigraphic sequence of the Picos de Europa province. This study focuses on the Caliza de Montaña (Montaña Beds) and the Picos de Europa Formation as highlighted on the figure (modified after Gomez-Fernandez et al., 2000). 

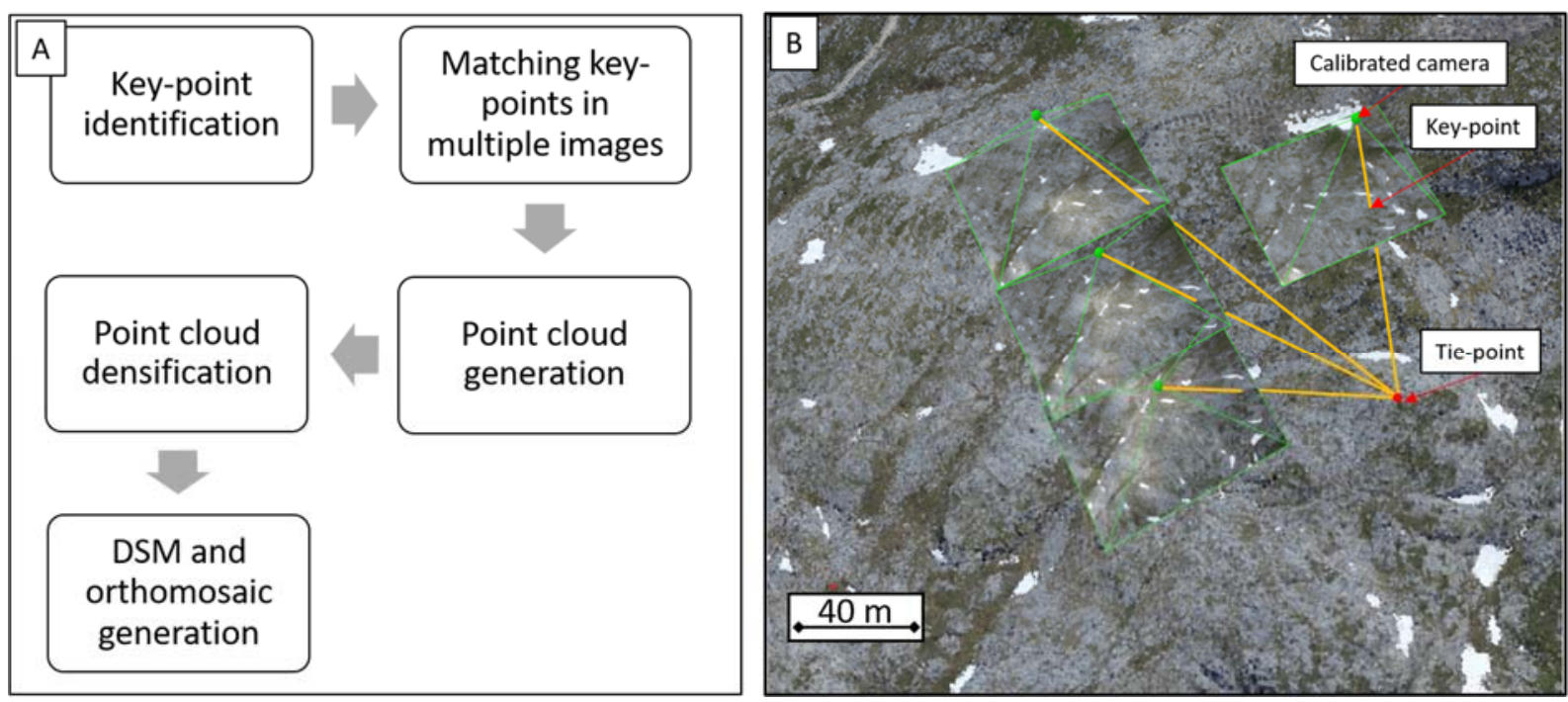

Figure 4. Schematic illustration of SfM photogrammetry for the creation of a 3D model from overlapping aerial photographs. (A) SfM photogrammetry workflow diagram. (B) Identical keypoints are observed in four overlapping images captured by the drone's camera and are subsequently used for reconstructing camera position and an object coordinate (tie-point). The background image is an aggregate of dense point clouds, whereas the four front pictures are thumbnails of drone captured images. Note that although thumbnails are presented next to each other and much smaller than the background image, they show overlapping pictures of the area presented.
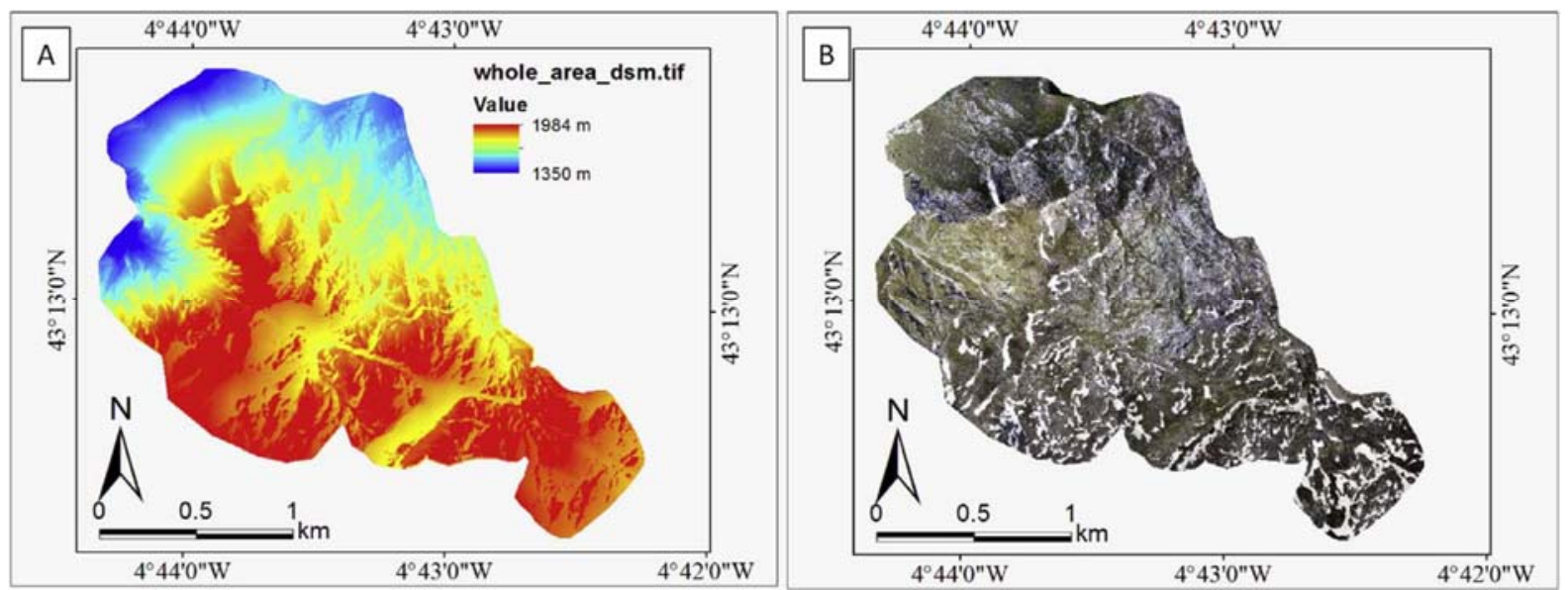

Figure 5. (A) DSM of the study area with spatial resolution of $25 \mathrm{~cm}$. The altitude ranges from $1350 \mathrm{~m}$ to $1984 \mathrm{~m}$. (B) Orthomosaic of the study area with spatial resolution of $25 \mathrm{~cm}$. 

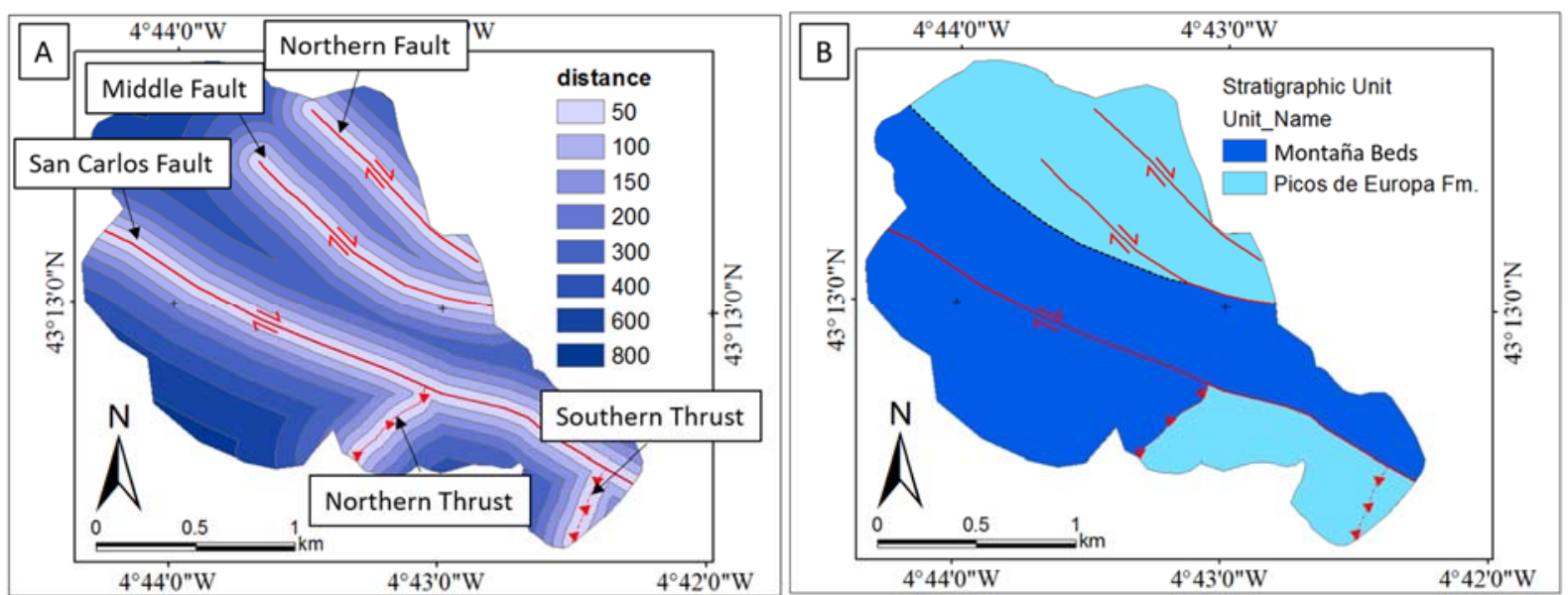

Figure 6. (A) Fault proximity map showing various distance intervals (values in $\mathrm{m}$ ) to investigate the distribution of dolomite bodies as a function of distance from the nearest faults. (B) The geological map of the study area based on the Careña-Cabrales map by Garcia et al. (1977).
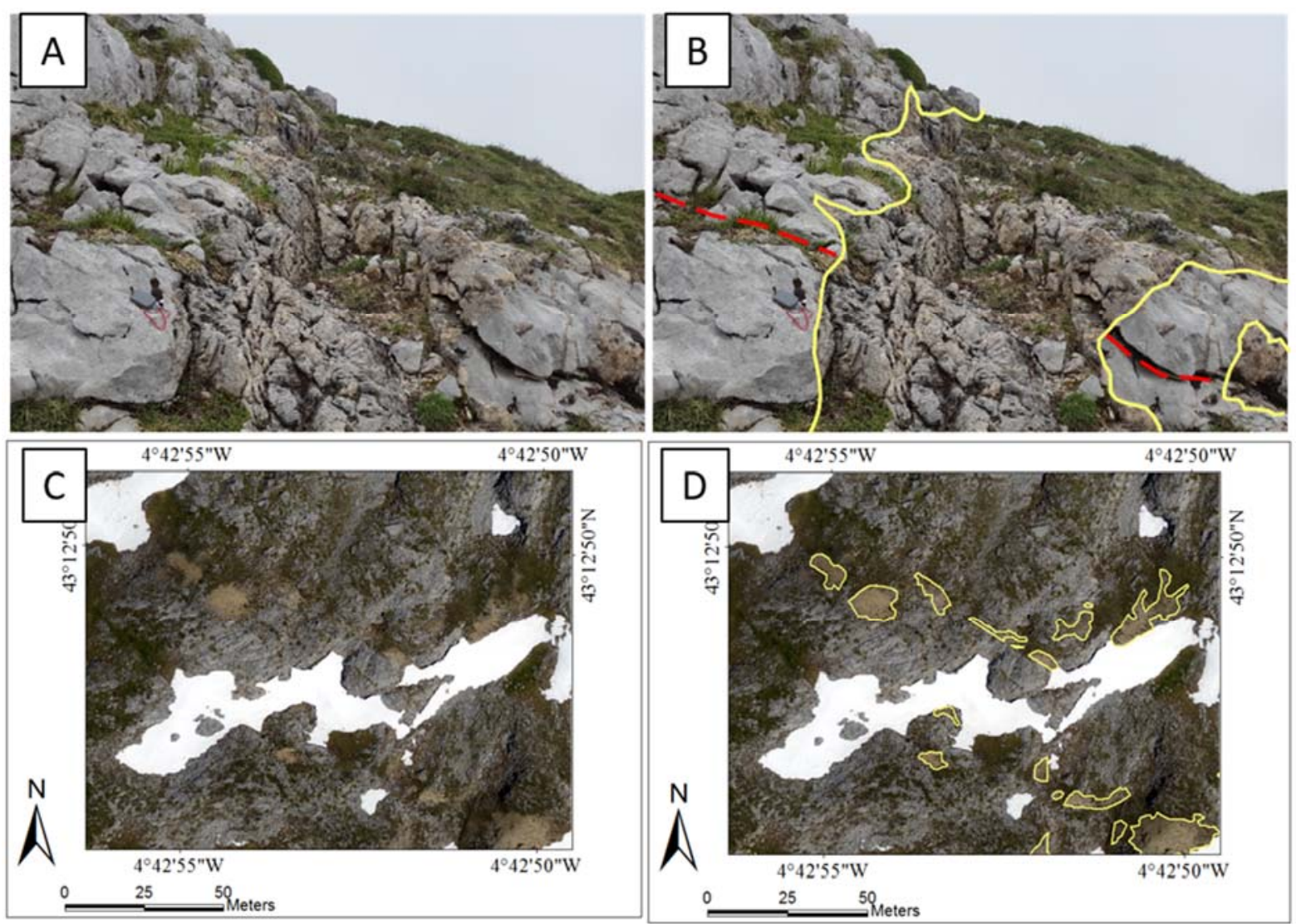

Figure 7. Distinction of dolomite bodies from limestone at different observation scales. Contacts between dolomite and limestone are marked in yellow. (A) Uninterpreted and (B) interpreted outcrop photograph of dolomite body and host limestone, with field compass for scale. The limestone bedding is indicated by a red dashed line, whereas dolomite bodies are delineated by a yellow line. The picture also illustrates the colour difference and the more fractured texture of the brown dolomite versus the more massive nature of the grey limestone. (C) Uninterpreted and (D) interpreted aerial photograph consisting of irregularly-shaped dolomite bodies (delineated by a yellow line) and host limestone. 


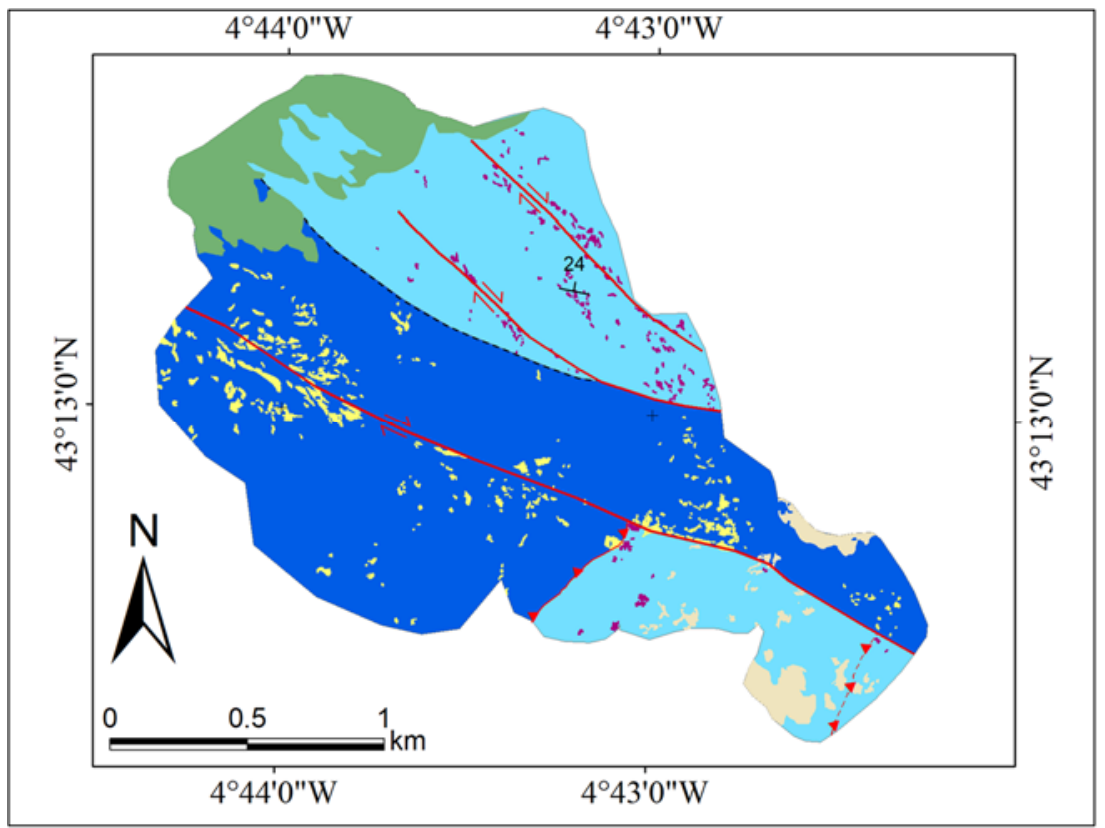

' Stratigraphic Contact

24 Strike \& Dip

Montaña Beds' hosted

dolomite

Picos de Europa Fm.

hosted dolomite

Area with extensively grass covered

Undifferentiated scree and abandoned mine pit

Figure 8. Detailed interpreted map of dolomite bodies in the study area. The uninterpreted model is presented in Figure $5 \mathrm{~B}$, and an example of uninterpreted and interpreted aerial photograph is presented in Figure 7C-D. The northwestern limit of the study area is mainly covered by grass, whereas the southeastern part of the study area contains regions covered by scree and abandoned mine pits. The dolomite bodies cover a slightly larger surface area in the Montaña Beds than in the Picos de Europa Formation, and they are slightly more concentrated close to strike-slip faults. The majority of the bodies are less than $30 \mathrm{~m}$ long and less than $15 \mathrm{~m}$ wide. 

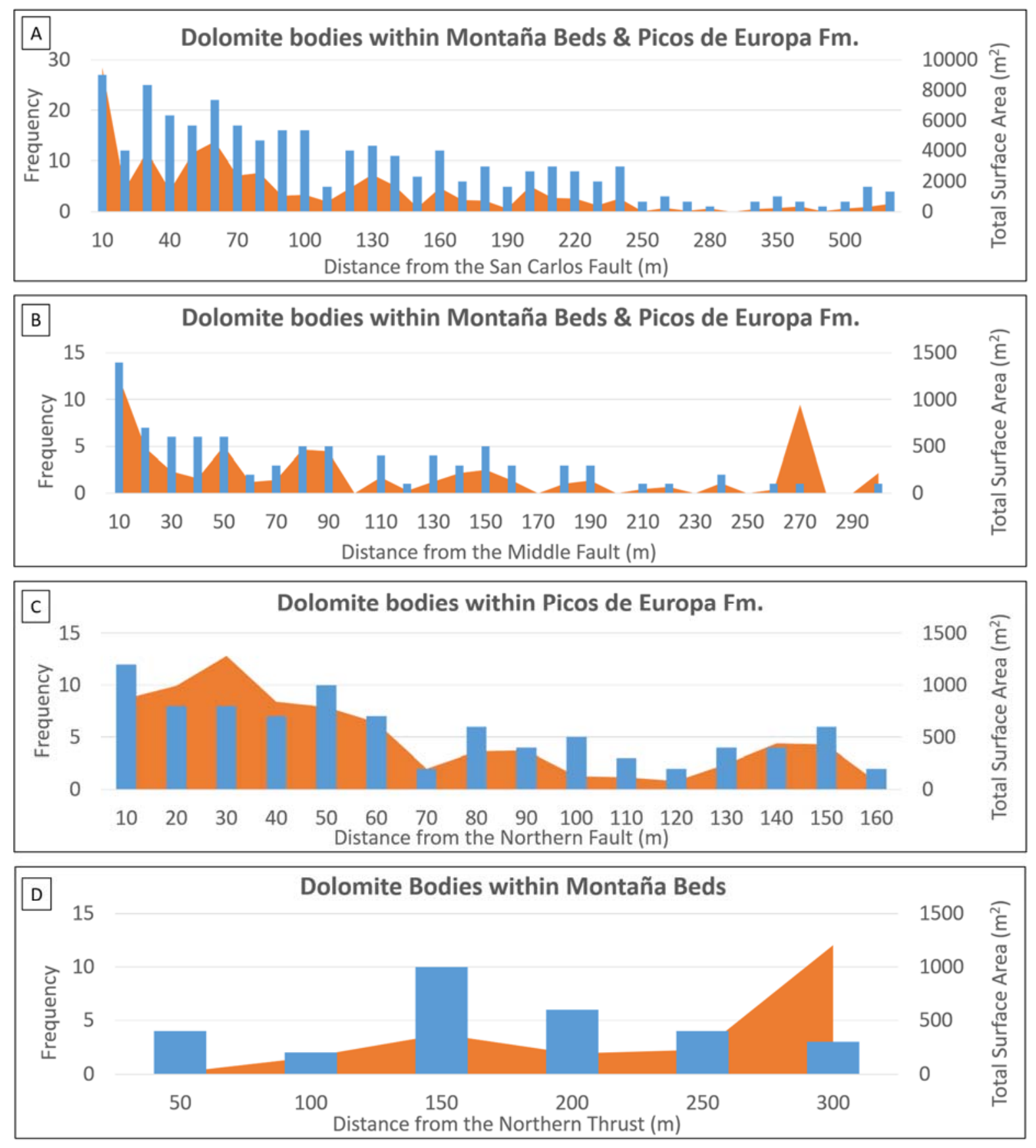

Frequency $\square$ Total surface area

Figure 9. The number and total surface area of dolomite bodies as a function of distance from (A) the San Carlos Fault, (B) the Middle Fault, (C) the Northern Fault, and (D) the Northern Thrust. There are only two dolomite bodies of area $162 \mathrm{~m}^{2}$ within $150 \mathrm{~m}$ of the Southern Thrust in the Picos de Europa Formation in the study area. 

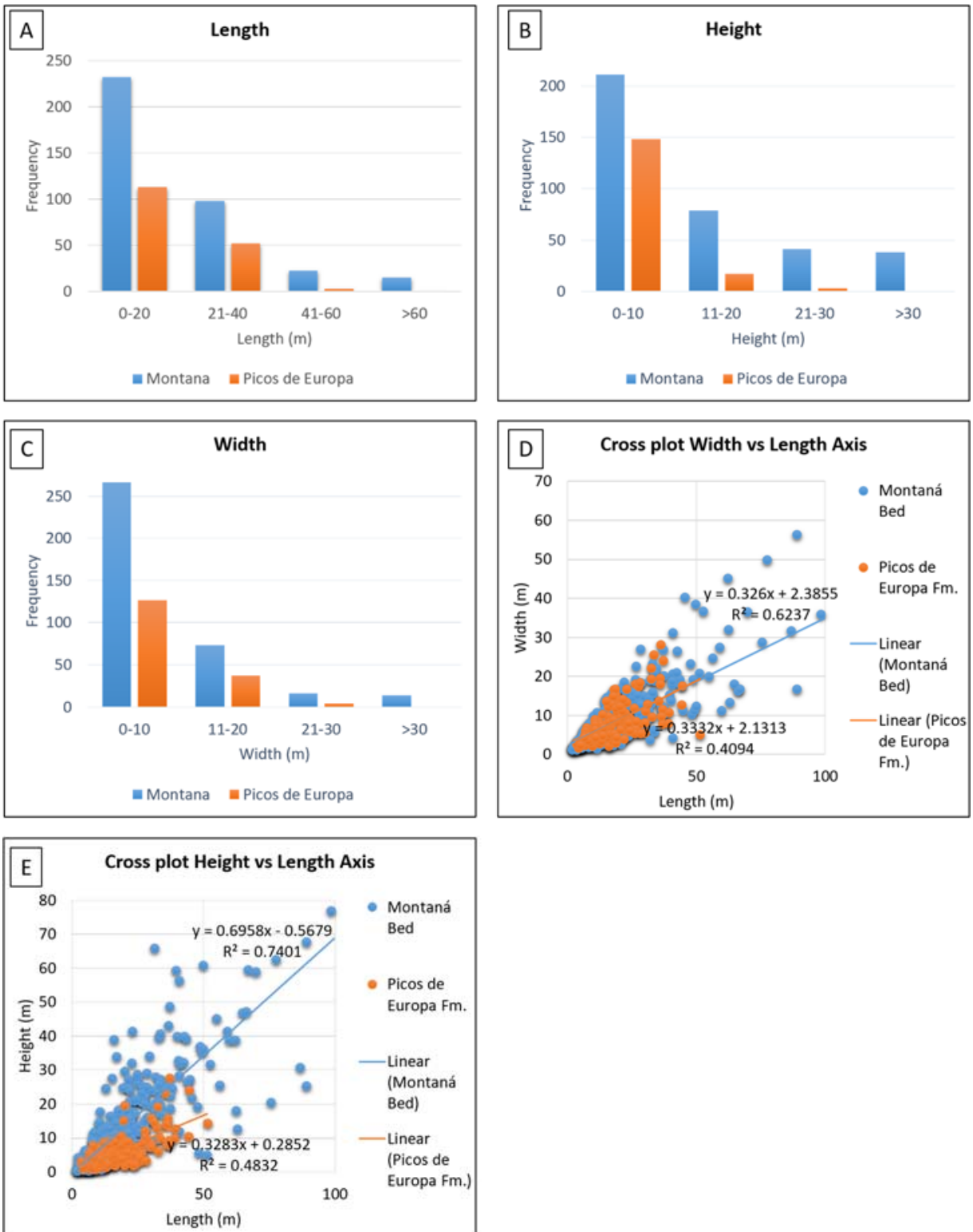

Figure 10. Histograms of (A) length, (B) height, and (C) width of the dolomite body's dimensions, and cross plots of dolomite body (D) width versus length and (E) height versus length.

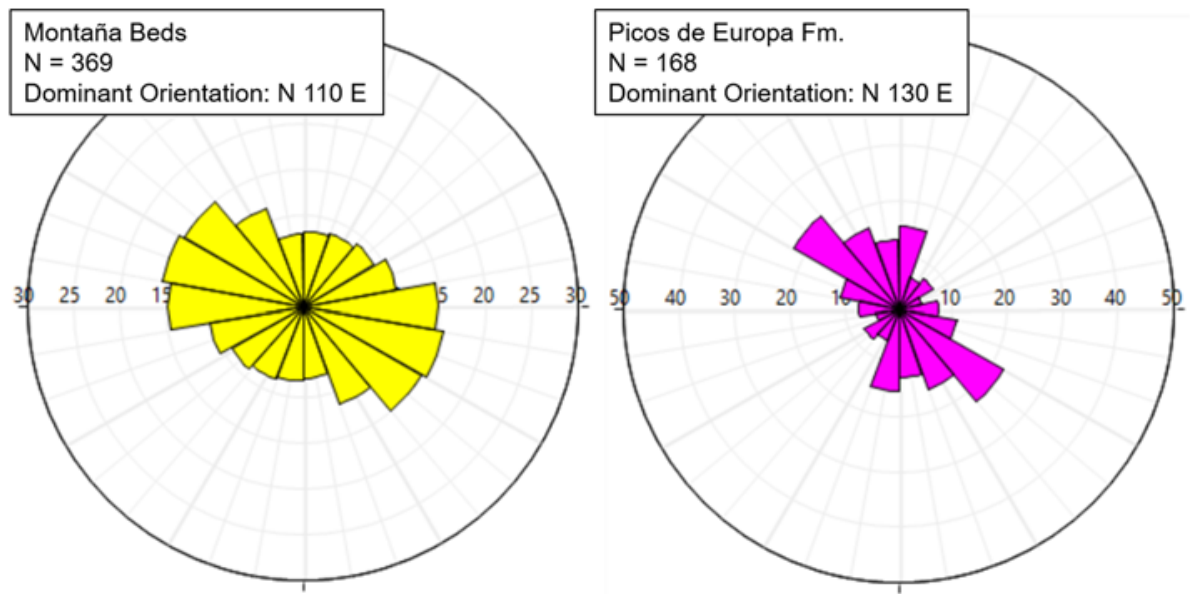

Figure 11. Rose diagrams of the orientation of the dolomite body long axes, showing a dominant NNW-ESE to NW-SE orientation. 
Table 1. Processing quality report of all models

\begin{tabular}{|c|c|c|c|c|c|c|c|c|c|c|}
\hline \multirow[b]{2}{*}{ No. } & \multirow{2}{*}{$\begin{array}{c}\text { Model } \\
\text { name }\end{array}$} & \multirow{2}{*}{$\begin{array}{c}\text { Total } \\
\text { area } \\
\text { covered } \\
(\mathrm{km} 2)\end{array}$} & \multirow{2}{*}{$\begin{array}{l}\text { Average } \\
\text { Ground } \\
\text { Sampling } \\
\text { Distance } \\
\text { (cm) }\end{array}$} & \multirow{2}{*}{$\begin{array}{l}\text { Median of } \\
\text { Key-points } \\
\text { (per } \\
\text { calibrated } \\
\text { image) }\end{array}$} & \multirow{2}{*}{$\begin{array}{l}\text { Median of } \\
\text { Matches } \\
\text { (per } \\
\text { calibrated } \\
\text { image) }\end{array}$} & \multirow{2}{*}{$\begin{array}{c}\text { Over- } \\
\text { lapping } \\
\text { images } \\
\text { (per } \\
\text { each } \\
\text { pixel) }\end{array}$} & \multirow{2}{*}{$\begin{array}{l}\text { DSM and } \\
\text { ortho- } \\
\text { mosaic } \\
\text { resolution } \\
\text { (cm) }\end{array}$} & \multicolumn{3}{|c|}{$\begin{array}{c}\text { Absolute } \\
\text { Geolocation RMS } \\
\text { Errors }\end{array}$} \\
\hline & & & & & & & & $\begin{array}{c}X \\
(m)\end{array}$ & $\begin{array}{c}Y \\
(m)\end{array}$ & $\begin{array}{c}Z \\
(m)\end{array}$ \\
\hline 1 & $\begin{array}{l}\text { full } \\
\text { model }\end{array}$ & 3.7 & 6 & 3147 & 1058 & $>5$ & 25 & 4 & 4 & 23 \\
\hline 2 & day 2 & 0.77 & 6 & 45653 & 25843 & $>5$ & 6 & 3 & 4 & 5 \\
\hline 3 & day 3 & 0.99 & 5 & 3059 & 992 & $>5$ & 20 & 2 & 3 & 2 \\
\hline 4 & day 4 & 1 & 6.5 & 3556 & 1350 & $>5$ & 13 & 3 & 4 & 3 \\
\hline 5 & day 6 & 0.56 & 10 & 3321 & 1658 & $>5$ & 10 & 6 & 2 & 3 \\
\hline 6 & day 8 & 0.78 & 5.5 & 3014 & 1154 & $>5$ & 5 & 4 & 2 & 1 \\
\hline 7 & day 9 & 1.5 & 9 & 3126 & 1116 & $>5$ & 9 & 3 & 3 & 7 \\
\hline 8 & day 10 & 0.91 & 6 & 3287 & 1329 & $>5$ & 6 & 2 & 2 & 4 \\
\hline
\end{tabular}

